\title{
Lack of Response of Some Food Crops to the Application of Synthetic Soil Conditioners to A Clay Soil in Lajas Valley
}

\section{A. Lugo-López, J. A. Bonnet, M. Rico-Ballester, and G. Acevedo'}

\section{INTRODUCTION}

The soils of the Lajas Valley in southwestern semiarid Puerto Rico present unique problems of soil management and use, particularly since the development of irrigation facilities in that area (2) ${ }^{2}$. They are deep, have a uniformly high clay content, and a very high proportion of small pores through which water moves rather sluggishly. Many of them present practical drainage and salinity problems (4).

A rather intensive program of research is under way to determine the soil- and crop-management techniques that will provide for the maximum utilization and conservation of those soils. The rather recent development of synthetic soil conditioners claimed to improve soil physical conditions suggests study of them and their effects.

This paper reports on a field experiment designed to determine the influence of synthetic soil conditioners on soil properties and crop yields under the conditions prevailing in the Lajas Valley.

\section{MATERIALS AND METHODS}

The experimental field was located on the farm of the Agricultural Experiment Substation on the outskirts of the town of Lajas in southwestern Puerto Rico. The soil is a typical Santa Isabel clay, a compact soil of the terraces and alluvial fans, probably a Reddish Chestnut or Planosol. The surface soil is black (5 YR 2/1) with a moderately developed structure changing to dark reddish-brown (5 YR 3/3) at a 13-inch depth. The aggregates are medium to large and rather densely packed, particularly at lower depths. It turns reddish-brown or yellowish-brown at 45 inches, with many small water-worn pebbles embedded in the clay matrix. Permeability is slow or very slow and the majority of the pores are very small (3). The soil contains abundant feldspars of the oligoclase, albite, and labradorite varieties with kaolin and illite dominating the clay fraction (6).

\footnotetext{
1 Associate Soil Scientist, Head of the Department of Soils, Research Assistant in Agronomy, and Research Assistant in Soils, respectively, Agricultural Experiment Station, University of Puerto Rico, Río Piedras and Lajas, P. R. Appreciation is expressed to $R$. Vázquez, who helped in laying out the experiment, and to $R$. PérezEscolar who determined the stability of the soil aggregates.

${ }^{2}$ Italic numbers in parentheses refer to Literature Cited, p. 172.
} 
The experiment was laid out following a balanced incomplete block design with 13 treatments, including control untreated plots, replicated four times in a 13-block arrangement. The plots were 4 feet $\times 6$ feet in size. The materials used were formulations 6 and 9 of Krilium, dry powder, 100-percent active ingredient; Aerotil, dry powder, 40-percent active ingredient; and Goodrite, flakes, 87-percent active ingredient. Each chemical was used at three rates: $900,1,800$, and 3,600 pounds to the acre. The conditioners were applied on May 25, 1954, and were carefully mixed with the uppermost 6 inches of soil. The check plots received the same mechanical treatment as the conditioner-treated plots to minimize any possible differences other than those imposed by treatment.

Three crops were grown on the same plots in the following sequence: Tomatoes, white beans, and sweetpotatoes. The plots were irrigated whenever indicated by a 9-inch deep-mercury tensiometer. Tomatoes, Plamar variety, were planted on June 24, 1954, at a distance of 2 feet. A 9-10-5 fertilizer was applied at the rate of 800 pounds to the acre. The plants were sprayed several times during the season with DDT and Copper A compound to keep pests under control. The tomatoes were harvested on August 28, September 2, 9, and 17, and October 1, 4, 11, and 18, 1954. The plots received 28 inches of rain and 8 inches of irrigation water. White beans, Bonita selection, were planted on November 2 at a 4 -inch distance, and received the same fertilizer as did the tomatoes. After 2 weeks the plants were thinned to two per hill. They were sprayed with a 4-percent solution of DDT twice during the growing period. The beans were all harvested on January 1, 1955. An irrigation of 2 inches of water was given to supplement the 4.5 inches of rainfall, of which 3.5 fell during the month of November.

Sweetpotatoes, variety UPR No. 3, were planted on July 1, 1955. They were fertilized with an 8-8-13 fertilizer at the same rate as the previous two crops. Pests were kept under control by spraying with Aldrin, DDT, and $\mathrm{BHC}$ at various times during the growing period. On November 15-16, the sweet potatoes were harvested. The 30 inches of rain during the growing season were supplemented with 8 inches of irrigation water.

Undisturbed soil cores were taken to a depth of 3 inches, as well as disturbed soil samples from selected plots on November 15, 1955, prior to harvesting the sweetpotato crop, and some 18 months after applying the treatment differentials. Aggregate stability of the 3-2 mm.-size fraction was determined according to the procedure of Bryant, Bendixen, and Slater (5). Quick drainage, porosity, bulk density, and water retention at $\mathrm{pF}$ 1.78 were determined by standard procedures. 


\section{RESULTS AND DISCUSSION}

Table 1 presents data on the production of tomatoes, white beans, and sweetpotatoes. The over-all differences of the treated over the check plots were not significant. The yields of Plamar tomatoes, the first crop in the sequence, were rather poor. The plants were healthy when transplanted, but they were badly attacked by fungi diseases, especially by stem rot, mainly because of the heavy August and September rains (over 16 inches,

TABLE 1.-Mean yields of tomatoes, white beans, and sweetpotatoes grown consecutively on Santa Isabel clay treated with soil conditioners

\begin{tabular}{|c|c|c|c|c|c|}
\hline \multirow{2}{*}{ Treatment No. } & \multirow{2}{*}{ Treatment } & \multirow{2}{*}{ Rate } & \multicolumn{3}{|c|}{$\begin{array}{l}\text { Crop yields in hundredwcights to } \\
\text { the acre of- }\end{array}$} \\
\hline & & & Tomatoes & Beans & $\begin{array}{c}\text { Sweet- } \\
\text { potatoes }\end{array}$ \\
\hline $\begin{array}{r}1 \\
2 \\
3 \\
4 \\
5 \\
6 \\
7 \\
8 \\
9 \\
10 \\
11 \\
12 \\
13\end{array}$ & $\begin{array}{c}\text { Check } \\
\text { Krilium } 9 \\
\text { do. } \\
\text { do. } \\
\text { Krilium } 6 \\
\text { do. } \\
\text { do. } \\
\text { Aerotil } \\
\text { do. } \\
\text { do. } \\
\text { Goodrite } \\
\text { do. } \\
\text { do. }\end{array}$ & $\begin{array}{r}\text { Pounds per acre } \\
0 \\
3,600 \\
1,800 \\
900 \\
3,600 \\
1,800 \\
900 \\
3,600 \\
1,800 \\
900 \\
3,600 \\
1,800 \\
900\end{array}$ & $\begin{array}{r}10.4 \\
31.3 \\
18.2 \\
13.6 \\
17.7 \\
13.2 \\
12.6 \\
15.4 \\
10.0 \\
7.7 \\
20.9 \\
30.4 \\
13.2\end{array}$ & $\begin{array}{l}18.6 \\
19.5 \\
16.3 \\
14.6 \\
16.4 \\
19.5 \\
19.1 \\
16.3 \\
16.4 \\
16.5 \\
18.2 \\
19.5 \\
16.8\end{array}$ & $\begin{array}{l}126.7 \\
139.0 \\
112.0 \\
128.7 \\
153.4 \\
149.7 \\
121.1 \\
155.7 \\
119.8 \\
137.9 \\
121.4 \\
129.4 \\
166.8\end{array}$ \\
\hline \multicolumn{3}{|c|}{$\begin{array}{l}\text { L.S.D. at the 5-percent level } \\
\text { L.S.D. at the 1-percent level }\end{array}$} & $\begin{array}{l}21.7 \\
29.0\end{array}$ & $\begin{array}{l}4.1 \\
5.5\end{array}$ & $\begin{array}{r}81.0 \\
109.1\end{array}$ \\
\hline
\end{tabular}

more than half of total rain during the growing period). The rather intensive spraying program could not keep these infections under control because of the frequent showers. The yields of Bonita white beans were good for all plots and no differences could be attributed to the treatment differentials. Total yields of sweetpotatoes surpassed 5 tons to the acre, in all cases with a large proportion of them well-shaped and marketable.

Lugo-López, et al. (7), working in the vicinity of Corozal, measured the beneficial effects of soil conditioners upon some crops, particularly on root crops like sweetpotatoes. Pérez-Escolar and Lugo-López (8) at Aibonito, obtained increases in potato yields from conditioner-treated plots, but found that stringless bean yields on the same plots were unaffected by 
treatments. The responses obtained at these two locations were explained on the basis of the increased stability of soil structural units produced by the addition of conditioning chemicals. At Corozal the stability of Lares clay aggregates was increased from 25 to 32 and over 45 percent, depending upon the chemicals used. At Aibonito, the water-stable aggregates of Juncos clay increased from almost 67 percent in the untreated plots to 73-91 percent, depending on the chemicals used and their concentrations. At the latter location, no responses were obtained with the bean crop in

Table 2.-Water-slable aggregates in a Santa Isabel clay soil treated with structure-stabilizing chemicals

\begin{tabular}{l|c|c}
\hline Treatment & Rate & $\begin{array}{c}3-2 \mathrm{~mm} \text {. water-stable } \\
\text { aggregates }\end{array}$ \\
\hline & Pounds per acre & Percent \\
Check & 0 & 57 \\
Krilium 9 & 3,600 & 63 \\
Krilium 6 & 3,600 & 57 \\
Aerotil & 3,600 & 62 \\
Goodrite & 3,600 & 50 \\
\hline
\end{tabular}

TABLE 3.-Bulk-density and soil-moisture data of a Santa Isabel clay with and without Krilium 9 present

\begin{tabular}{c|c|c|c|c|c}
\hline Treatment & Rate & Bulk density & $\begin{array}{c}\text { Water drained } \\
\text { at 60-cm. } \\
\text { tension in } \\
15 \text { minutes }\end{array}$ & $\begin{array}{c}\text { Maximum } \\
\text { saturation }\end{array}$ & $\begin{array}{c}\text { Water retained } \\
\text { at } \mathrm{pF} 1.78\end{array}$ \\
\hline & $\begin{array}{ccc}\text { Pounds per acre } \\
\text { Check }\end{array}$ & Gns./cc. & Percent & Percent & Percent \\
Krilium 9 & 0 & 0.96 & 5.2 & 64.6 & 51.0 \\
Do. & 3,600 & .83 & 7.2 & 65.2 & 46.5 \\
Do. & 1,800 & .94 & 5.6 & 62.8 & 50.7 \\
& 900 & .91 & 5.8 & 65.4 & 48.8 \\
\hline
\end{tabular}

contrast to the potato crop. This stresses the significance of recognizing plant differences when assessing the influence of improved soil physical conditions upon crop growth and production (8).

The soil conditioners did not affect the stability of Santa Isabel clay soil aggregates in the experimental plots at the Lajas Substation farm, as shown in table 2.

Table 3 shows that the bulk density and water movement and retention in the upper 3 inches of Santa Isabel clay were not affected by soil conditioners. The structural units of the uppermost 6-inch layer of this soil have a naturally rather high water stability which cannot, and need not be further increased with chemical additives. Some of the soils of the 
Lajas Valley have an upper layer, sometimes extending down to 24 inches, with a very high fertility level, that can maintain a somewhat favorable physical condition due to the high percentage of stable aggregates. Other soils present more difficult management problems, including salinity and alkalinity hazards.

Under such conditions the action of synthetic soil conditioners may promote increased soil-aggregate stability and improved soil physical conditions (1). However, the very high costs of these products will for some time limit their widespread use in general farming, even in areas where problem soils could be improved by their action. There is need of more fundamental information concerning soil properties, particularly soil structure and aggregate stability, prior to the extension of research or action programs with synthetic soil conditioners of the type tested in these experiments. The possibilities of using cheaper materials of organic origin should not be overlooked.

\section{SUMMARY}

Data are presented here from a field experiment where Krilium 6 and 9, Aerotil, and Goodrite (dry powder of the first three and flakes of the fourth) were applied to the uppermost 6 inches of a Santa Isabel clay soil at the Lajas Valley, each at rates of $900,1,800$, and 3,600 pounds to the acre. Three crops: Tomatoes, white beans, and sweetpotatoes, were grown in the sequence following the establishment of the treatment differentials. None of the crops showed any response to the soil-conditioning chemicals. The stability of the soil aggregates of Santa Isabel clay, which is naturally high, was not affected by the treatment. The data presented show also that the water movement and retention and other soil physical properties remain unaffected by treatment. The lack of response is discussed and compared with other problem soils where crop responses have been measured.

\section{RESUMEN}

Se presentan aquí datos sobre un experimento de campo donde se aplicó Krilium 6, Krilium 9, Aerotil, y Goodrite (los tres primeros en polvo seco, y el ultimo en hojuelas) a las primeras 6 pulgadas del suelo Santa Isabel arcilloso en el Valle de Lajas.

Se produjeron consecutivamente tomates, habichuelas blancas y batatas mameyas en las parcelas después de establecer los tratamientos. Ninguna de estas cosechas respondió en lo más mínimo al tratamiento con acondicionadores de suelos. Estos resultados se discuten a la luz de los obtenidos en otros suelos problemas donde hubo aumentos en los rendimientos y considerando que la estabilidad de las unidades estructurales del suelo 
Santa Isabel arcilloso es alta por naturaleza y no fué afectada por los tratamientos. Se presentan además datos que demuestran que el movimiento y retención de humedad, así como otras propiedades físicas del suelo, no fueron afectados por los tratamientos con los acondicionadores de suelos usados.

\section{LITERATURE CITED}

1. Allison, L. E., Effect of synthetic polyelectrolytes on the structure of saline and alkali soils, Soil Sci. 73(6) 443-54, 1952.

2. Bonnet, J. A., and Tirado Sulsona, P., Soil Studies in the Lajas Valley. Univ. P. R. Agr. Exp. Sta. Bul. 86, 1950.

3. Bonnet, J. A., et al., Annual report of the Department of Soils, Project S-14. Univ. P. R. Agr. Exp. Sta. (unpublished), 1955.

4. Bonnet, J. A., and Brenes, E. J., Salinity status of Lajas Valley soils, J. Agr. Univ. P.R. 41(1) 25-34, 1957.

5. Bryant, J. C., Bendixen, T. W., and Slater, C. W., Measurement of water stability of soils, Soil Sci. 66 341-5, 1948.

6. Jeffries, C. D., Bonnet, J. A., and Abruña, F., The constituent minerals of some soils of Puerto Rico, J. Agr. Univ. P.R. 37(2) 114-39, 1953.

7. Lugo-López, M. A., Bonnet, J. A., and Pérez-Escolar, R., The effect of lime and synthetic soil conditioners on crop yields and soil aggregation, J. Agr. Univ. P. R. 41(3) 179-88, 1957.

8. Pérez-Escolar, R., and Lugo-López, M. A., The effect of synthetic soil conditioners on soil-aggregate stability and production of potatoes and stringless beans, $J$. Agr. Univ. P. R. 41(2) 127-33, 1957. 